\title{
The Comparative Law of Climate Change: A Research Agenda
}

\section{Michael Mehling*}

Climate change defies traditional models of academic enquiry; its scale and complexity strain the explanatory power of established thought, prompting the espousal of new, fluid concepts and calls for greater interdisciplinarity. Law, with its rigid doctrines and ostensibly dated insistence on binary categories, appears particularly unsuited as a framework of analysis. But as this article submits, the legal method offers a unique vessel to infer collective understandings of the climate challenge, helping bridge the divide between facts and norms that characterizes other intellectual paradigms. A shifting focal point from international to domestic climate action suggests the particular utility of comparative law, which can identify policy barriers and drivers, and add a vital dimension to the study of policy learning and transfer. Invoking the epistemic value of legal exegesis, this article proposes a research agenda for comparative analysis in a rapidly evolving issue area, which, although not yet a field of law in its own right, offers many opportunities for fruitful study: the law as it relates to climate change.

\section{INTRODUCTION}

Comparative law is not usually thought of in terms of its epistemic strength. It is an instrumental exercise that is expected to yield useful insights into the commonalities and differences of legal systems, at best allowing deduction of normative patterns that transcend the boundaries of geography and time. As this article suggests, however, comparative legal analysis may hold an underappreciated promise: to provide access, through an established methodology, to the expression of collective will embedded in the law. In the case of technically complex and morally contingent challenges such as climate change, this capacity of comparative study may contribute to our understanding of the opportunities for meaningful solutions, as well as the obstacles to their implementation. Following a discussion of the epistemology of climate action and the role of jurisprudence therein, this article therefore proposes a research agenda for comparative legal analysis in the context of climate change.

\section{LAW AND THE EPISTEMOLOGY OF CLIMATE ACTION}

\section{AN UNFULFILLED CONSENSUS}

\footnotetext{
* Corresponding author.

Email: mmehling@mit.edu
} 
'Climate change is the greatest threat faced by humankind.' Thus, or in similar terms, have leaders in government and administration, ${ }^{1}$ industry, ${ }^{2}$ faith, ${ }^{3}$ civil society ${ }^{4}$ and academia ${ }^{5}$ described the climate challenge, reflecting widespread public concern about the expected consequences of a changing atmosphere. ${ }^{6}$ Long a matter of contention, ${ }^{7}$ the underlying science has mostly become settled, supported by growing evidence of early climate impacts. ${ }^{8}$ Yet remarkably, while the threat of climate change has been acknowledged at the highest levels of public authority for over half a century, ${ }^{9}$ progress in addressing its principal cause - the accumulation of greenhouse gases in the atmosphere - has been consistently outpaced by emissions growth in most parts of the world. ${ }^{10}$ Even recurrent

\footnotetext{
1 'Climate change is the defining issue of our age ... We have never faced such a challenge.' Ban Ki-moon (Secretary-General of the United Nations), 'Opening Remarks at 2014 Climate Summit' (New York, 23 September 2014), found at: $<$ http://www.un.org/apps/news/infocus/sgspeeches/statments_full.asp?statID=2355\#.VdSvSod7ye0>. 'And no challenge - no challenge - poses a greater threat to future generations than climate change.' B. Obama (President of the United States), 'Remarks by the President in State of the Union Address' (Washington, DC, 20 January 2015), found at: $<\mathrm{https} / /$ www.whitehouse.gov/the-press-office/2015/01/20/remarks-presidentstate-union-address-january-20-2015>.

2 'Climate change is a critical challenge for our world.' BG Group et al., Letter to Her Excellency Ms. Christiana Figueres and His Excellency Mr. Laurent Fabius (1 June 2015), found at: $<$ http://www.bp.com/en/global/corporate/press/press-releases/oil-and-gas-majors-call-for-carbon-
} pricing.html>.

${ }^{3}$ ' $[T]$ he gravest challenge that humanity has ever faced.' T. Gyatso (13 ${ }^{\text {th }}$ Dalai Lama) et al., 'The Time to Act is Now: A Buddhist Declaration on Climate Change' (14 May 2015), found at: $<\mathrm{http}: / /$ www.ecobuddhism.org/bcp/all_content/buddhist declaration>. 'Climate change is a global problem with grave implications.' J.M. Bergoglio (Pope Francis), Encyclical Letter Laudato si' of the Holy Father Francis on Care for Our Common Home (Rome, 24 May 2015), found at: $<$ http://w2.vatican.va/content/francesco/en/encyclicals/documents/papa-francesco_20150524_enciclicalaudato-si.html>, at paragraph 25. See also International Islamic Climate Change Symposium, 'Islamic Declaration on Global Climate Change' (Istanbul, 17-18 August 2015), found at: $<\mathrm{http}$ ://islamicclimatedeclaration.org/islamic-declaration-on-global-climate-change $>$.

4 'Climate change is life or death. It is the new global battlefield.' Wangari Maathai, winner of the Nobel Peace Prize, cited in: J. Vidal, 'Global Warming Causes 300,000 Deaths a Year, Says Kofi Annan Thinktank', The Guardian (29 May 2009).

5 'Climate change is the greatest challenge of our time.' T.F. Stocker, Co-Chair of Working Group I of the Intergovernmental Panel on Climate Change (IPCC), cited in: J. Gillis, 'U.N. Climate Panel Endorses Ceiling on Global Emissions', New York Times (27 September 2013).

${ }^{6}$ Pew Research Center, 'Climate Change Seen as Top Global Threat' (Pew Research Center, 2015), found at: $\quad<$ http://www.pewglobal.org/files/2015/07/Pew-Research-Center-Global-Threats-Report-FINAL-July14-2015.pdf $>$.

${ }^{7}$ For a discussion of the politicization of climate science, see D. Demeritt, 'The Construction of Global Warming and the Politics of Science', 91:2 Annals of the Association of American Geographers (2010), 307; N. Oreskes, 'The Scientific Consensus on Climate Change', 306:5702 Science (2004), 1686.

${ }^{8}$ Intergovernmental Panel on Climate Change (IPCC), Climate Change 2014: Impacts, Adaptation, and Vulnerability. Contribution of Working Group II to the Fifth Assessment Report of the Intergovernmental Panel on Climate Change (Cambridge University Press, 2014), at 4; World Bank, Turn Down the Heat: Confronting the New Climate Normal (World Bank Group, 2014), at xvii.

${ }^{9}$ See, e.g., Lyndon B. Johnson, Special Message to the US Congress (Washington, DC, 8 February 1965): 'Air pollution is no longer confined to isolated places. This generation has altered the composition of the atmosphere on a global scale through ... a steady increase in carbon dioxide from the burning of fossil fuels.'

${ }^{10}$ Intergovernmental Panel on Climate Change (IPCC), Climate Change 2013: The Physical Science Basis. Contribution of Working Group I to the Fifth Assessment Report of the Intergovernmental Panel on Climate Change (Cambridge University Press, 2013), at 12-13. 
affirmations of the technical feasibility ${ }^{11}$ and economic rationale of broad decarbonization ${ }^{12}$ have failed to spur momentum for adequate action, ${ }^{13}$ casting a surreal light on admonitions, published with predictable regularity, that the 'window of opportunity' to avoid dangerous climate change is perpetually about to close. ${ }^{14}$

Academic scholarship has dedicated considerable resources across multiple disciplines to diagnose the reasons for this 'global warming gridlock'. ${ }^{15}$ A challenge distinct from other environmental threats, anthropogenic climate change originates in diffuse and virtually ubiquitous activities, with boundless geographic scope matched only by an almost indefinite time horizon. Lingering uncertainties about climate sensitivity and damage functions impede a straightforward assessment of the costs and benefits of different policy options, ${ }^{16}$ creating an exceptionally wide realm of acceptable discourse for the many asymmetrical interests - both narrow individual and broad societal - affected by climate change or a policy response. ${ }^{17}$ It is this confluence of scale, complexity, and contingence that has prompted climate change to be designated a 'super-wicked' problem, ${ }^{18}$ engendering a political debate fraught with ideological acrimony. ${ }^{19}$

\section{LIMITATIONS OF THE SOCIAL SCIENCES}

And there, precisely, lies the diagnostic potential of academic research. When a threat of unrivalled magnitude is largely confirmed and technical solutions have become widely

\footnotetext{
${ }^{11}$ On environmental problems that resist a solution despite availability of technical solutions, see R. Costanza, 'Social Traps and Environmental Policy', 37:6 Bioscience (1987), 407, at 408.

${ }^{12}$ F. Calderón et al., Better Growth, Better Climate: The New Climate Economy Report (Global Commission on the Economy and Climate, 2014); J. Channel et al., Energy Darwinism II: Why a Low Carbon Future Doesn't Have to Cost the Earth (Citi, 2015); Council of Economic Advisers, The Cost of Delaying Action to Curb Climate Change (Executive Office of the President of the United States, 2014); J. Sachs et al., Pathways to Deep Decarbonization (Sustainable Development Solutions Network et al., 2014); N. Stern (2007), The Economics of Climate Change (Cambridge University Press, 2007). On the importance of the economic cost of policy, see R. Pielke, Jr., The Climate Fix: What Scientists and Politicians Won't Tell You About Global Warming (Basic Books, 2010), at 46.

${ }^{13}$ On the persistent 'emissions gap' between currently committed and scientifically admonished emission reductions, see United Nations Environment Programme (UNEP), The Emissions Gap Report 2014 (UNEP, 2014), at 26; see also D. Helm, 'Climate-Change Policy: Why Has So Little Been Achieved?', 24:2 Oxford Review of Economic Policy (2008), 211.

${ }^{14}$ See most recently, e.g., an editorial in a leading academic journal: 'Window of Opportunity', 4 Nature Climate Change (2014), 1037.

${ }^{15}$ E.B. Skolnikoff, 'The Policy Gridlock on Global Warming', 79 Foreign Policy (1990), 77.

${ }^{16}$ W.D. Nordhaus, The Climate Casino: Risk, Uncertainty, and Economics for a Warming World (Yale University Press, 2013); R.S. Pindyck, 'The Climate Policy Dilemma', 7:2 Review of Environmental Economics and Policy (2014), 219; M.L. Weitzman, 'Fat Tails and the Social Cost of Carbon', 104:5 American Economic Review (2014), 544.

${ }^{17}$ See A. Fleming et al., 'Challenging Dominant Discourses of Climate Change', 127:3 Climatic Change (2014), 407.

${ }^{18}$ R. Lazarus, 'Super Wicked Problems and Climate Change: Restraining the Present to Liberate the Future', 94:5 Cornell Law Review (2009), 1153, going back to H.W.J. Rittel and M.M. Webber, 'Dilemmas in a General Theory of Planning', 4:2 Policy Sciences (1973), 155.

${ }^{19}$ M. Hulme, Why We Disagree About Climate Change: Understanding Controversy, Inaction, and Opportunity (Cambridge University Press, 2009).
} 
available, the absence of a suitable response - despite nearly universal endorsement cannot be properly explained by the natural or applied sciences. If anything, one should seek an answer from the disciplines traditionally focused on human behaviour and individual or collective decision making. Among these, economics stands out for its disproportionate influence on climate policy, ${ }^{20}$ ascribing climate change to different market failures ${ }^{21}$ and unrestricted access to the atmosphere as a common pool resource. ${ }^{22}$ With a coherent paradigm and expanding use of empirical methods, it introduces numerical precision and the promise of objectivity - both highly seductive to policy makers - in an ideological debate. But where the elegant abstractions and corrective prescriptions ${ }^{23}$ of mainstream economics are known to fall short is in their ability to account for the social, institutional, and cultural dimensions of climate change, not to mention the irrationality of the attendant politics. ${ }^{24}$

Other social sciences have long claimed that territory as their domain. With its high stakes, diverse actors and comprehensive scope, climate change has attracted different areas of social research as a fertile source of case studies and proven testing ground for hypotheses. And this wealth of research has undoubtedly contributed explanatory value by studying how societies perceive the threat of climate change and organize around common responses. Owing to the diverse toolbox of social scientists, we now have a better appreciation for the role of institutions, interests, and ideas in shaping climate action. More widespread use of evidence-based methods, in particular, has fundamentally changed our

\footnotetext{
${ }^{20}$ Affirming that trained economists have dominated IPCC Working Group III author teams for several assessment reports, for instance: E. Corbera et al., 'Patterns of Authorship in the IPCC Working Group III Report', Nature Climate Change (2015, forthcoming), at 3; A. Bjurström and M. Polk, 'Physical and Economic Bias in Climate Change Research: A Scientometric Study of IPCC Third Assessment Report', 108:1 Climatic Change (2011), 1; D. Victor, 'Embed the Social Sciences in Climate Policy', 520:7545 Nature (2015), 27; for the relevance of economics generally, see W.J. McKibbin and P.J. Wilcoxen, 'The Role of Economics in Climate Change Policy', 16:2 Journal of Economic Perspectives (2002), 107.

${ }^{21}$ Climate change was famously described as 'the greatest market failure the world has ever seen' by $\mathrm{N}$. Stern, n. 12 above, at viii. More aptly, however, it is the result of several failures of the market to allocate goods and services efficiently, including positive and negative externalities, the bounded rationality of economic actors, and information asymmetries; for a seminal description of the concept, see F.M. Bator, 'The Anatomy of Market Failure', 72:3 Quarterly Journal of Economics (1958), 351.

${ }^{22}$ E. Ostrom, Governing the Commons: The Evolution of Institutions for Collective Action (Cambridge University Press, 1990), at 15.

${ }^{23}$ Mainly an explicit or implicit carbon pricing to internalize the social cost of emissions, see A. Bowen, The Case for Carbon Pricing (London School of Economics and Political Science, 2011); on the importance of internalizing the externalities of polluting behaviour, see: W.J. Baumol and W.E. Oates, The Theory of Environmental Policy, $2^{\text {nd }}$ edn (Cambridge University Press, 1988), at 155.

${ }^{24}$ Criticizing the narrow focus of neoclassical economics on the individual choices of rational actors in the marketplace: R.J. Brulle and R.E. Dunlap, 'Sociology and Global Climate Change: Introduction', in: R.E. Dunlap and R.J. Brulle (eds.), Climate Change and Society: Sociological Perspectives (Oxford University Press, 2015), 1, at 8; heterodox schools of economics, such as institutional and behavioural economics, which include psychological, social, cognitive, and emotional factors in their analysis of economic choices, still face paradigmatic challenges, such as the methodological focus on marginal change, the identification of a discount rate for long time scales, questions of distribution, and how to value irreversible damages, see generally N. Stern, 'Ethics, Equity and the Economics of Climate Change. Paper 1: Science and Philosophy', 30:3 Economics and Philosophy (2014), 397; and N. Stern, 'Ethics, Equity and the Economics of Climate Change. Paper 2: Economics and Politics', 30:3 Economics and Philosophy (2014), 445.
} 
understanding of the effects of different policies on human behaviour and the environment. ${ }^{25}$ Likewise, innovative technologies to assemble and process large sets of empirical data promise the discovery of previously unknown correlations and causal pathways.

And yet, despite these advances in our knowledge base, we are forced to concede that the climate challenge remains as intractable as ever, with efforts to formulate a commensurate response becoming, if anything, more circuitous and open-ended. A cynical observer might even claim that most important insights from the social sciences were already revealed decades ago, and that contributions since have been largely limited to providing greater nuance and granularity, occasionally applying new, imaginative labels to familiar phenomena. A cursory survey of climate research by two leading social scientists, for instance, affirms remarkable consistency in diagnosis and central policy recommendations over multiple decades. ${ }^{26}$ That their recommendations have not found implementation over such a long period of time raises the question whether we also face a 'research gridlock' a condition where scholarly enquiry has become trapped in a recursive cycle of selfreferential investigation, accentuated by periodic variations on the underlying themes, and with aspirational prescriptions forever unable to capture the coarse realities of practice.

If all we can hope for from the social sciences going forward are incremental improvements in our understanding of the reasons for inaction, observing how the first- and second-best policy recommendations of pure theory are ignored or altered in the political process and - often enough symbolic - compromises enacted in their stead, anyone hoping to meaningfully advance the climate effort could be forgiven for bypassing academic research altogether, likening the exercise to the rearrangement of deck chairs on a sinking vessel. But the scientific process rarely produces instant solutions, least of all for sweeping challenges such as climate change; and if there is a solution, it will almost certainly not be a simple one. Every insight, however small, on the human dimensions of this unique threat forms an important contribution to a larger epistemic process, out of which the countless

\footnotetext{
${ }^{25}$ S.E. Ryan, C. Hebdon and J. Dafoe, 'Energy Research and the Contributions of the Social Sciences: A Contemporary Examination', 3 Energy Research \& Social Science (2014), 186, at 193.

${ }^{26}$ Four decades ago, economist W.D. Nordhaus discussed solutions ranging from emissions reductions even mentioning a phase-out of fossil fuels - to emissions sequestration and what is now commonly known as geoengineering; see W.D. Nordhaus, Can We Control Carbon Dioxide? (International Institute for Applied Systems Analysis, 1975), at 6-8; this catalogue of options, along with his preferred policy recommendation, a price on carbon emissions, recur in his 2013 book The Climate Casino, n. 16 above, at 221. Likewise, his diagnosis that climate change is an externality problem that incentivizes freeriding can be traced back to W.D. Nordhaus, Strategies for the Control of Carbon Dioxide (Yale University, 1977), at 19-20, and also underlies his recent Presidential Address to the American Economic Association in January 2015, published as: W.D. Nordhaus, 'Climate Clubs: Overcoming Free-riding in International Climate Policy', 105:4 American Economic Review (2015), 1339. Meanwhile, the scepticism about comprehensive, legally binding institutions for climate governance based on universal participation and quantified targets and timetables expressed in research by political scientist D.G. Victor can be consistently tracked across two decades of research starting with D.G. Victor, 'How to Slow Global Warming', 349:6309 Nature (1991), 451, through D.G. Victor and J.E. Salt, 'Keeping the Climate Treaty Relevant', 373:6512 Nature (1995), 280, to D.G. Victor, 'Toward Effective International Cooperation on Climate Change: Numbers, Interests and Institutions', 6:3 Global International Politics (2006), 90, and D.G. Victor, Global Warming Gridlock (Cambridge University Press, 2011).
} 
fragments of our aggregate response will ultimately emerge. But still, to propose an answer to the query raised earlier in this section, the social sciences hold no monopoly on the correct answer to climate change.

\section{A ROLE FOR JURISPRUDENCE}

One aspect of the climate threat that has arguably been insufficiently addressed is its normative dimension. Although the explanatory value of empirical research cannot be overstated, no amount of observation can replace the difficult value judgments involved in determining the proper course of action. ${ }^{27}$ Humanities, and notably ethics, play an essential role in understanding different concepts of value and justice, the underlying arguments, and how they might guide our choices. ${ }^{28}$ In the pluralist breadth of its prescriptions, ethics also serves as a powerful testament to the normative contingency of climate change. ${ }^{29}$ Another normative discipline that has played a largely subordinate role in the debate about climate change is jurisprudence, ${ }^{30}$ and this essay asks whether the law, and more specifically comparative law, offers an underutilized tool to understand, predict, and shape climate policy choices. But what might a discipline contribute that neither provides observational insight based on empirical analysis, nor can ascend a scaffolding of robust theory to summon innovative policy designs?

Overall, the legal profession enjoys a paltry reputation in the context of climate policy, and has even been implicitly blamed for the slow progress in finding a global solution. ${ }^{31}$ Lawyers will generally be invited to apply their professional skills to climate policy only when legal technicalities are at stake, for instance to comment on a legal dispute or the legality of a proposed measure. In part, this relative isolation of the legal discipline can be ascribed to its distinctive terminology, professional culture, and a claim to authority based on reflexive interpretation of legal sources rather than observation of measurable phenomena. In the language of systems theory, law forms a closed, autopoietic social

\footnotetext{
${ }^{27}$ Intergovernmental Panel on Climate Change (IPCC), Climate Change 2014: Mitigation of Climate Change. Contribution of Working Group III to the Fifth Assessment Report of the Intergovernmental Panel on Climate Change (Cambridge University Press, 2014), at 213-214; see also O. Edenhofer and M. Kowarsch, 'Cartography of Pathways: A New Model for Environmental Policy Assessments', 51 Environmental Science \& Policy (2015), 56.

${ }^{28}$ For excellent overviews of the attendant issues, see D.A. Brown, Climate Change Ethics: Navigating the Perfect Moral Storm (Routledge, 2012); S.M. Gardiner, A Perfect Moral Storm: The Ethical Tragedy of Climate Change (Oxford University Press, 2011); J. Garvey, The Ethics of Climate Change: Right and Wrong in a Warming World (Bloomsbury Academic, 2008); D. Jamieson, Reason in a Dark Time: Why the Struggle Against Climate Change Failed - And What It Means for Our Future (Oxford University Press, 2014).

${ }^{29}$ For an illustration of how ethical arguments of distributive and corrective justice can also result in very different policy prescriptions, contrast E.A. Posner and D. Weisbach, Climate Change Justice (Princeton University Press, 2010); and H. Shue, Climate Justice: Vulnerability and Protection (Oxford University Press, 2014).

${ }^{30}$ See, e.g., S.J. Adams-Schoen et al., 'A Response to the IPCC Fifth Assessment', 45:1 Environmental Law Reporter (2015), 10027.

${ }^{31}$ See, e.g., economist J. Sachs, quoted in: 'UN Issued with Roadmap on How to Avoid Climate Catastrophe', The Guardian (8 July 2014), as saying of the UNFCCC negotiation process: 'It put the lawyers out front and left the technologists out of the room, and the result is that we have had 21 years of lawyering and no success in application of the international framework.'
} 
system that postulates binary statements on the legality - or lack thereof - of individual and collective behaviour. ${ }^{32}$ Any measure taken by public authorities, for instance, will emerge into a densely populated system of doctrines, rules, and principles across all areas of social life ${ }^{33}$ that determine its validity and shape its implementation. Lawyers operating within this system will communicate in their professional vernacular as they leverage an established canon of hermeneutic methods to unlock the normative patterns woven into the dense fabric of the law. Although they can also step back and take an external view on the law and how it affects the world, ${ }^{34}$ other disciplines - such as sociology and anthropology - provide more valuable tools for an external observation; ${ }^{35}$ but knowledge of the law and how it operates - that is, proficiency in legal exegesis - remains indispensable to understand its internal logic and dynamic application.

Trained in the distinctive methods of their discipline, lawyers can make an important contribution to the epistemology of climate action. At this time in human history, where faith in universal truths based on a foundational premise has been largely replaced by a fluid pluralism of secular ideas, ${ }^{36}$ the only way of accessing a challenge involving unprecedented degrees of complexity, uncertainty and moral contingency is arguably through a consensual approach, built on a process of orderly discourse between free and equal subjects. ${ }^{37}$ In democratic societies, lawmaking provides a structured process of deliberation and justification to distil a multitude of contending perceptions and interests into a uniform narrative ${ }^{38}$ that, importantly, also affords participatory rights to otherwise marginalized segments of society. ${ }^{39}$ Unquestionably, the processes of law creation are, even at their best, far from the ideal of enlightened discourse, ${ }^{40}$ and therefore must entail

\footnotetext{
${ }^{32}$ G. Teubner, Law as an Autopoietic System (Blackwell Publishers, 1993); N. Luhmann, Das Recht der Gesellschaft (Suhrkamp, 1993), at 38.

${ }^{33}$ As Niklas Luhmann described it, '[a]ll collective human life is directly or indirectly shaped by law. Law is, like knowledge, an essential and all-pervasive fact of the social condition. No area of life - whether it is the family or the religious community, scientific research or the internal networks of political parties - can find a lasting social order that is not based on law.' N. Luhmann, A Sociological Theory of Law (Routledge \& Kegan Paul, 1985), at 1 .

${ }^{34}$ F. Ewald, 'The Law of Law', in: G. Teubner (ed.), Autopoietic Law: A New Approach to Law and Society (Walter de Gruyter, 1988), 36.

${ }^{35}$ E. Örücü, 'Developing Comparative Law', in: E. Örücü and D. Nelken (eds.), Comparative Law: A Handbook (Hart, 2007), 43, at 48.

${ }^{36}$ At least in large parts of the world, if not all; see generally Z. Bauman, Liquid Modernity (Polity, 2000); U. Beck, Risikogesellschaft: Auf dem Weg in eine andere Moderne (Suhrkamp, 1986); A.C. MacIntyre, Whose Justice? Which Rationality? (University of Notre Dame Press, 1988).

${ }^{37}$ For the theoretical foundations of such a consensus theory of truth, see the ouvre of Jürgen Habermas on the theory of communicative action, e.g.: J. Habermas Vorstudien und Ergänzungen zu einer Theorie des kommunikativen Handelns (Suhrkamp, 1984), at 177-178; for alternative proposals to harness collective judgment for complex and contingent problems, see S. Funtowicz and J. Ravetz, 'Science for the Post-Normal Age', 25:7 Futures (1993), 735; J. Surowiecki, The Wisdom of Crowds (Doubleday, 2004); and, in a narrower sense, M. Polanyi, 'The Republic of Science: Its Political and Economic Theory', 1:1 Minerva (1962), 54.

${ }^{38}$ J. Habermas, Faktizität und Geltung (Suhrkamp, 1992), at 499.

${ }^{39}$ While it may do so for marginalized groups in the present, it offers little accountability towards future generations, see H. Jonas, Das Prinzip Verantwortung: Versuch einer Ethik für die technologische Zivilisation (Suhrkamp Verlag, 1979), at 55.

${ }^{40}$ Aggregative concepts of democracy have been recognized to face numerous challenges, for instance the disproportionate impact of powerful interest groups, a passive citizenry, or information asymmetries among
} 
an unconditional commitment to further improvement; but for better or for worse, law currently offers the most formal expression of political consensus, enshrining the outcomes of contentious political debate in the categories of material rules and principles.

As a direct result, barriers to climate action may also be deeply embedded in the sediment of law as principles and doctrines, some of which may even far predate our knowledge of climate change. Indeed, the legal system is, by its very nature, a conservative force in society, sustaining the normative patterns and understandings that precipitated the climate crisis in the first place. ${ }^{41}$ Using the methods of their profession, lawyers can draw on this substrate to infer defensible interpretations through an established process of legal reasoning, ${ }^{42}$ bringing to light previously concealed obstacles to climate ambition, mapping the space for permissible action, and, wherever necessary, applying accepted criteria to balance the tensions and conflicts that will inevitably arise across different rights, duties, and objectives in the context of climate change. ${ }^{43}$ One need not subscribe to notions of the intrinsic determinacy of the law ${ }^{44}$ to recognize that its routines offer, on a practical level, greater transparency and certainty than raw anarchic debate, creating a space for discourse in which the legal process moderates the extremes that often dominate political deliberation.

Like the social sciences, therefore, law and its methods will not reveal a miraculous solution to the threat of climate change; but lawyers can do more than resolve disputes or ascertain the legality of climate policy proposals: in a debate characterized by a cacophony of competing voices, they offer access to the most robust expression of collective will, and do so through a process that perpetuates - as much as possible - the legitimacy of its interpretations, ultimately increasing the acceptability of practical outcomes.

\section{COMPARATIVE LEGAL ANALYSIS AND CLIMATE CHANGE}

\section{THE DOMESTIC TURN IN CLIMATE ACTION}

its members, see J.F. Bohman, Public Deliberation: Pluralism, Complexity, and Democracy (MIT Press, 2000); J.S. Dryzek, Deliberative Democracy and Beyond: Liberals, Critics, Contestations (Oxford University Press, 2000). Critics have therefore suggested that periodic elections and the principal-agent form of representation as an expression of aggregate preferences are insufficient bases of political authority, which instead needs to be justified to all those who will be bound by it through a process of collective reasoning and active public debate, see A. Gutmann and D. Thompson, Why Deliberative Democracy? (Princeton University Press, 2004). For a scathing critique of parliamentary democracy, see C. Schmitt, Die geistesgeschichtliche Lage des heutigen Parliamentarismus (Duncker \& Humblot, 1923).

${ }^{41}$ F. Capra and U. Mattei, The Ecology of Law: Toward a Legal System in Tune with Nature and Community (Berrett-Koehler Publishers, 2015).

${ }^{42}$ For an authoritative discussion, see N. MacCormick, Legal Reasoning and Legal Theory (Clarendon Press, 1978), at 265-274.

${ }^{43}$ For an interpretive theory based on the notion of the integrity of law, see R.M. Dworkin, Law's Empire (Harvard University Press, 1986), at 90.

44 See, for instance, R.M. Dworkin, 'No Right Answer?', in: P.M.S. Hacker and J. Raz (eds.), Law, Morality, and Society: Essays in Honour of H.L.A. Hart (Clarendon Press, 1977), 58, at 58-84. 
Applying a jurisprudential paradigm to broader societal debates is not a new idea, and has, for instance, been proposed to better understand and improve international environmental governance. ${ }^{45}$ Climate change is, of course, the quintessential global challenge, crying out for better governance at the international level. ${ }^{46}$ So if law and the legal profession are to play a role in its solution, it would stand to reason that international law - the law traditionally governing the conduct of nation States - is the most appropriate level of engagement. And indeed, for more than two decades, the international community focused its efforts on diplomatic negotiations under the auspices of a multilateral treaty, the United Nations Framework Convention on Climate Change (UNFCCC). ${ }^{47}$ But as negotiations have repeatedly broken down, regained momentum, and faltered again, attention has increasingly shifted to the national and even local level, ${ }^{48}$ prompting extensive debate about the merits of international law and casting doubt on the possibility of a comprehensive global solution. ${ }^{49}$

What matters, however, is that this pivot has not only occurred in isolated strands of academic scholarship: Against a backdrop of at best sporadic progress in the international negotiations, domestic climate action has positively flourished in the last handful of years. ${ }^{50}$ Along with this shifting centre of gravity come far-reaching implications for the role of law in climate policy. Unlike the realm of international relations, where lawless anarchy is the default condition unless punctuated by ratified treaty obligations or the elevated threshold of general international law, ${ }^{51}$ domestic jurisdictions are entirely built around a dense structure of binding, hard rules. A central barrier to multilateral

45 W.F. Baber and R.V. Bartlett, Consensus and Global Environmental Governance: Deliberative Democracy in Nature's Regime (MIT Press, 2015), at 31.

${ }^{46}$ See, e.g., J.B. Wiener, 'Think Globally, Act Globally: The Limits of Local Climate Change Policies', 155:6 University of Pennsylvania Law Review (2007), 1961.

${ }^{47}$ United Nations Framework Convention on Climate Change (UNFCCC) (New York, 9 May 1992; in force 21 March 1994).

${ }^{48}$ E. Diringer, 'Climate Change: A Patchwork of Emissions Cut', 501:7467 Nature (2013), 307.

${ }^{49}$ See, e.g., K.W. Abbott, 'The Transnational Regime Complex for Climate Change', 30:4 Environmental Planning C (2011), 571; S. Barrett and M. Toman, Contrasting Future Paths for an Evolving Global Climate Regime (World Bank, 2010); R.O. Keohane and D.G. Victor, 'The Regime Complex for Climate Change', 9:1 Perspectives on Politics (2011), 7; S. Rayner, 'How to Eat an Elephant: A Bottom-up Approach to Climate Policy', 10:6 Climate Policy (2010), 615; R.B. Stewart, M. Oppenheimer, and B. Rudyk, 'A New Strategy for Global Climate Protection', 120:1 Climatic Change (2013), 1; D.G. Victor, J.C. House, and S. Joy, 'A Madisonian Approach to Climate Policy', 309:5742 Science (2005), 1820. For an excellent overview, see A.J. Jordan et al., 'Emergence of Polycentric Climate Governance and its Future Prospects', Nature Climate Change (2015, forthcoming).

${ }^{50}$ See, e.g., M. Nachmany et al., The 2015 Global Climate Legislation Study: A Review of Climate Change Legislation in 99 Countries (GLOBE International et al., 2015); N.K. Dubash et al., 'Developments in National Climate Change Mitigation Legislation and Strategy’, 13:6 Climate Policy (2013), 649; and below, text accompanying $\mathrm{n} .85$ to 89 .

${ }^{51}$ PCIJ 7 September 1927, The Case of the S.S. 'Lotus' (France v. Turkey), [1927] PCIJ Ser. A, No. 10, at 18: 'Restrictions upon the independence of States cannot ... be presumed.' Some degree of lawmaking has now been conceded to international bodies such as the Conference of the Parties to the UNFCCC, although the boundaries remain somewhat hazy, see J. Brunnée, 'COPing with Consent: Law-making under Multilateral Environmental Agreements', 15:1 Leiden Journal of International Law (2002), 1; R.R. Churchill and G. Ulfstein, 'Autonomous Institutional Arrangements in Multilateral Environmental Agreements: A Little-noticed Phenomenon in International Law’, 94:4 American Journal of International Law (2000), 623. 
cooperation, the prospect of free riding by recalcitrant States, ${ }^{52}$ plays only a subordinate role in the domestic context, where public authority can coerce its subjects to observe climate mandates. Precisely this enforceability of domestic law is what has motivated many to place their hopes for climate progress on national and local rather than international action. Even successfully negotiated international arrangements take recourse to domestic law for their implementation, with transposition proving the Achilles heel of many an environmental regime, ${ }^{53}$ conversely, enactment of domestic law yields valuable experience and fosters debate that can increase the willingness to commit internationally. ${ }^{54}$ Given this pivotal role of domestic law in any effort to control climate change, the disproportionate attention bestowed on international diplomacy and institution building by the academy may seem surprising, although it will arguably persist, and for good reasons. ${ }^{55}$

\section{WHY COMPARATIVE LAW?}

If we agree that the focal point of climate action has shifted to the domestic level, we also have to ask ourselves what framework is best suited to study the legal ramifications of the transition. Where international lawyers have, by definition, dominated research on international climate cooperation within the legal discipline, no natural counterpart has emerged for domestic climate law. In fact, as will be shown in the next section, the very boundaries of this subject area remain in question, complicating its assignment to any established field of legal research. Lawyers with very diverse backgrounds, from environmental law to financial and energy market regulation, have engaged in the study of climate change and its intersection with domestic law; and while appropriate to the varied nature of the climate challenge, this eclectic approach is unlikely to provide a coherent paradigm for systematic investigation.

A defining feature of the climate challenge - its global scope - provides useful guidance on the question of suitable framing: Just as no single jurisdiction can solve climate change alone, it stands to reason that no particular legal system will yield all the insights that can potentially be garnered from academic study. Bearing in mind the urgency of climate

\footnotetext{
${ }^{52}$ See W.D. Nordhaus, n. 26 above, at 1339: 'Free-riding occurs when a party receives the benefits of a public good without contributing to the costs.' See also C. Gollier and J. Tirole, 'Negotiating Effective Institutions Against Climate Change' 4:2 Economics of Energy \& Environmental Policy (2015), 5; J. Stiglitz, 'Overcoming the Copenhagen Failure with Flexible Commitments', 4:2 Economics of Energy \& Environmental Policy (2015), 29.

${ }^{53}$ M. Mehling, 'Betwixt Scylla and Charybdis? Effectiveness in International Environmental Law', 13 Finnish Yearbook of International Law (2002), 129.

${ }^{54}$ T. Townshend and A.C.T. Matthews, National Climate Change Legislation: The Key to More Ambitious International Agreements (Climate \& Development Knowledge Network, 2013), at 2, citing C. Figueres, the Executive Secretary of the UNFCCC as saying 'Nothing is going to be agreed internationally until enough is legislated domestically'; see also T. Townshend et al., 'How National Legislation Can Help to Solve Climate Change', 3 Nature Climate Change (2013), 430, at 430; T. Townshend et al., 'Legislating Climate Change at the National Level'. 53:5 Environment (2011), 5, at 5.

${ }^{55}$ For a persuasive discussion of the importance of an international perspective, see W. Hare et al., 'The Architecture of the Global Climate Regime: A Top-down Perspective', 10:6 Climate Policy (2010), 600; the author also thanks an anonymous reviewer for reminding him about the significance of competitiveness and related concerns for political support of unilateral action.
} 
change, one might therefore argue that we cannot afford an overly narrow perspective. On the contrary, if law is to expand our understanding of the possibilities for addressing climate change, we should broaden the analysis to encompass as many different experiences and circumstances as possible, fostering a high level of policy learning and diffusion, and helping avoid costly mistakes. Rather than focus on a specific area of law in a specific jurisdiction, hence, this article suggests that the most promising approach to process insights across numerous legal systems will be one of comparative analysis.

As highlighted by Morgera in the introductory article to this special issue, comparative law is an established field of legal enquiry that focuses on the legal rules or norms, categories, and institutions in two or more legal systems to infer degrees of similarity and difference, drawing conclusions that the analysis of each system alone would not yield ${ }^{56}$ It allows the legal scholar to contrast a chosen feature of the law against its foreign counterparts, resulting in a dialectic perspective for knowledge progression. ${ }^{57}$ What it also takes into account, moreover, is the role of context. ${ }^{58}$ In an area as fraught with political and moral disagreement as climate change, it would be tempting to focus only on the most visible manifestation of norms, codified law. Yet existence of a written law does not necessarily say much about its social relevance, ${ }^{59}$ nor can the dynamics of its formulation and implementation be fully understood without taking into account broader socioeconomic circumstances. ${ }^{60}$ Comparative lawyers are therefore often encouraged to consider all factors that influence the structure, development and content of a particular legal system, including the 'economic and political systems, political ideology, history, geography and demographic factors'. 61

\footnotetext{
${ }^{56}$ E. Morgera, 'Global Environmental Law and the Comparative Legal Method', 24:3 Review of European, Comparative and International Environmental Law (2015).

${ }^{57}$ G. Samuel, An Introduction to Comparative Law Theory and Method (Hart, 2014), at 11.

${ }^{58}$ With an admonition not to ignore the historical and cultural context of different legal systems, for instance: M.A. Glendon, P.G. Carozza and C.B. Picker, Comparative Legal Traditions, $3^{\text {rd }}$ edn (Thomson West, 1999), at 13 .

${ }^{59}$ The very real dichotomy between enacted laws and their social application has, of course, been one of the oldest preoccupations of legal theory and sociology; see, e.g., E. Ehrlich, Grundlegung der Soziologie des Rechts (Duncker und Humblot: Munich, 1913), at 155; R. Pound, 'Law in Books and Law in Action', 44 American Law Review (1910), 12; M. Weber, Wirtschaft und Gesellschaft: Grundriß der Sozialökonomik, III. Abteilung (J.C.B. Mohr, 1922), at 368-389.

${ }^{60}$ What applies to advanced industrialized economies may be even more pertinent for developing nations, where the socioeconomic context of codified norms may be more important than their content; different countries show great variations in their legal and administrative systems, their regulatory cultures, and their traditions of transparency, accountability and access to information - weak enforcement capacities, less robust adherence to the rule of law, and an absence of effective civil society and public interest monitoring groups can therefore greatly undermine what would otherwise seem progressive legislation, ultimately rendering it symbolic; see, e.g., R.G. Bell, Choosing Environmental Policy Instruments in the Real World (OECD, 2003), at 11.

${ }^{61}$ J. Darpö and A. Nilsson, 'On the Comparison of Environmental Law', 3:1 Journal of Court Innovation (2010), 315, at 324 .
} 
With context, therefore, comes the question of interdisciplinarity. ${ }^{62}$ At a purely ontological or phenomenological level, the complexity and scale of climate change would indeed suggest a need to incorporate the contributions of other disciplines in an effort to understand the genesis, evolution, and implementation of legal responses to the challenge. ${ }^{63}$ And undoubtedly important synergies could be leveraged by engaging the epistemic outlook of neighbouring disciplines, such as the policy sciences, public administration, or governance studies. ${ }^{64}$ Often these will be equipped with superior methods and a conceptual framework that is better suited to generate knowledge about socioeconomic circumstances. A good example is policy transfer studies, a research theme developed across several disciplines premised on the observation that successful policy ideas do not always diffuse from one jurisdiction to another; ${ }^{65}$ it is easy to envision how the insights from that research agenda can enrich our understanding of the transferability of legal concepts and institutions.

But despite the obvious attraction of interdisciplinarity, comparative lawyers should resist the temptation to dilute or surrender that unique capacity of the legal method, namely to infer formal statements from the law which manifest the collective will embodied therein, as shaped and moderated by the sum of rules, principles and doctrines constituting the legal system. Where lawyers might feel called upon to broaden the scope of their enquiry, they risk venturing into areas where their native skillset places them at a disadvantage vis-à-vis disciplines with sophisticated qualitative and quantitative methods of empirical research. ${ }^{66}$

\footnotetext{
${ }^{62}$ Interdisciplinary research is a 'mode of research by teams or individuals that integrates information, data, techniques, tools, perspectives, concepts, and/or theories from two or more disciplines or bodies of specialized knowledge to advance fundamental understanding or to solve problems whose solutions are beyond the scope of a single discipline or field of research practice'; see National Academy of Sciences, National Academy of Engineering, and Institute of Medicine, Facilitating Interdisciplinary Research (National Academy Press, 2004), at 2.

${ }^{63}$ C.P. Carlarne, 'Exploring Methodological Challenges within the Context of Climate Change Law and Policy', 105 American Society of International Law Proceedings (2011), 255.

${ }^{64}$ Lawyers might, for instance, draw on the relevant intersection between comparative law and these other areas of study, such as comparative politics and its preoccupation with ideas, interests and institutions, public policy and its differentiated understanding of the policy cycle, economics and its ability to shed insight on the costs and benefits of alternative forms of action or the lack thereof, or psychology and its explanations of individual and collective behavioural responses to different policy incentives or constraints; see, e.g., K. Harrison and L.M. Sundstrom, 'Conclusion: The Comparative Politics of Climate Change', in K. Harrison and L.M. Sundstrom (eds.), Global Commons, Domestic Decisions: The Comparative Politics of Climate Change (MIT Press: 2010), 261, at 284-286; E. Lachapelle and M. Paterson, 'Drivers of National Climate Policy', 13:5 Climate Policy (2013), 547, at 548-550; M. Purdon, 'Advancing Comparative Climate Change Politics: Theory and Method', 15:3 Global Environmental Politics (2015), 1, at 2.

${ }^{65}$ For the seminal work setting out this research agenda, see D.P. Dolowitz and D. Marsh, 'Who Learns What from Whom? A Review of the Policy Transfer Literature', 44:2 Political Studies (1996), 343; and D.P. Dolowitz and D. Marsh, 'Learning from Abroad: The Role of Policy Transfer in Contemporary Policymaking', 13:1 Governance (2000), 5; for a more recent review of the state of the field, see D. Stone, 'Transfer and Translation of Policy', 33:6 Policy Studies (2012), 483.

${ }^{66}$ While, admittedly, such methods can be acquired through autodidactic study, such an approach will, at best, place considerable demands of time and effort on the lawyer and, at worst, yield outcomes that seem amateurish to formally trained members of the respective discipline; one reason is the heterogeneity of thought even within disciplines, each of which tends to entertain its own theoretical and methodological
} 
Collaborating in diverse teams will offer a more practical approach to interdisciplinary research, although there, too, challenges - such as ensuring equal weight and communication across disciplines - need to be overcome. ${ }^{67}$

On a deeper and more problematic level, interdisciplinarity can introduce the subtle value judgments, ideological orientations and ontological assumptions underlying other disciplines, or characterizing specific schools or theoretical paradigms within those disciplines. ${ }^{68}$ When interpreted through such external layers of normativity, the expression of collective will embedded in the law can easily become distorted. Lawyers may exercise an important corrective function by applying the exegetic skills of their profession, which, although not immune to instrumentalization, are still better suited to identifying the formal consent expressed within the law. Without venturing into a debate about the politics of interdisciplinarity, however, it may be safe to argue that lawyers will make the greatest contribution to knowledge progression by remaining sensitive to disciplinary boundaries and focusing on questions that leverage their distinct methodology, comparing features of the law from an internal point of view. ${ }^{69}$ A tentative research agenda, with questions that genuinely harness a comparative legal approach, will be suggested later in this article. But first, the common subject of analysis, in this case the legal response to climate change, calls for a clearer definition in order to make comparisons across jurisdictions. ${ }^{70}$

\section{CLIMATE LAW: A NASCENT FIELD OF LAW?}

Even if one rejects the limitation of comparative analysis to functionally equivalent features in each legal system, ${ }^{71}$ a high degree of conceptual precision is advisable to ensure that the object of juxtaposition, the tertium comparationis, is - if not teleological

debates; see J. Klabbers, 'The Relative Autonomy of International Law or the Forgotten Politics of Interdisciplinarity', 1:1-2 Journal of International Law and International Relations (2005), 35, at 37.

${ }^{67}$ H. Ledford, 'Team Science', 525:7569 Nature (2015), 308, at 310-311; in greater depth, V. Strang, 'Integrating the Social and Natural Sciences in Environmental Research', 11:1 Journal of Environment, Development and Sustainability (2009), 1, at 6.

${ }^{68}$ Here, for instance, one might think of the vastly different worldviews and assumptions underlying realist, idealist, constructivist, institutionalist and functionalist scholarship - to name but the major schools - in international relations, see M. Koskenniemi, 'Law, Teleology and International Relations: An Essay in Counterdisciplinarity’, 26:1 International Relations (2011), 3, at 19.

69 J.C. Reitz, 'How to Do Comparative Law', 46:4 American Journal of Comparative Law (1998), 617, at 628, citing W. Ewald, 'Comparative Jurisprudence (I): What Was It Like to Try a Rat?', 143:6 University of Pennsylvania Law Review (1995), 1889, at 1972-1973. In a sense, this view also underlies the functional method endorsed by many comparative law scholars, who recommend framing the analysis around common functions in each surveyed jurisdiction and cutting these 'loose from their conceptual context and stripped of their own national doctrinal overtones' so as to avoid being influenced by domestic preconceptions; see K. Zweigert and H. Kötz, An Introduction to Comparative Law, $3^{\text {rd }}$ edn (Oxford University Press, 1998 ), at 44. Admittedly, and somewhat inconsistently, Zweigert and Kötz also variously endorse consideration of socioeconomic factors other than the law.

${ }^{70}$ See J.C. Reitz, n. 69 above, at 620; on the importance of clear definitions for comparative analysis: T. Forsyth and L. Levidow, 'An Ontological Politics of Comparative Environmental Analysis: The Green Economy and Local Diversity’, 15:3 Global Environmental Politics (2015), 140.

${ }^{71}$ See, notably, K. Zweigert and H. Kötz, n. 69 above, at 32-47. 
counterparts in each jurisdiction ${ }^{72}$ - at least accurately defined and sufficiently circumscribed to allow for meaningful comparison. When comparing how legal systems have evolved in response to climate change, an intuitive first step would be to ask whether this evolution has given rise to a discrete body of law across jurisdictions, a discovery that would, in itself, be a noteworthy outcome of comparative analysis.

Going purely by the volume of academic activity, one might readily conclude that such an area of law has emerged, spawning a considerable number of university courses and textbooks, publications, and affiliated institutions. ${ }^{73}$ But on its own, the vibrancy of scholarly output is hardly a sufficient indicator for a new area of law. What really asks for an answer is whether climate change has resulted in a 'coherent, autonomous body of law or [is] nothing more or less than the application of national and international law to climate problems' ${ }^{74}$ Aside from being of academic interest, classification as a distinct field of law has real consequences: it can send a political signal and legitimize a topic, facilitate analysis and communication of the law, streamline its application for greater operational efficiency, and ultimately render it more adequate to the scale and impact of a societal project than a disjointed patchwork of unrelated rules and doctrines. ${ }^{75}$

No universal or even widely agreed set of criteria exist as to what constitutes an autonomous body of law, however, nor where thresholds for the degree of coherence and autonomy should be set. ${ }^{76}$ Sociologically, the emergence of a new area of law might be acknowledged through consensus within the epistemic community of legal professionals; ${ }^{77}$ materially, it can find its expression in a system of rules unified by common, overarching

\footnotetext{
72 See J. Darpö and A. Nilsson, n. 61 above, at 318.

${ }^{73}$ See, e.g., the journals Climate Law (Brill) and Carbon \& Climate Law Review (Lexxion); course textbooks such as R.G. Hildreth et al., Climate Change Law: Mitigation and Adaptation (West, 2009); J. Nolon and P. Salkin, Climate Change and Sustainable Development Law in a Nutshell (West Academic Publishing, 2010); H.M. Osofsky and L.K. McAllister, Climate Change Law and Policy (Aspen, 2012); C. Wold, D. Hunter and M. Powers, Climate Change and the Law, $2^{\text {nd }}$ edn (LexisNexis, 2013); M. Winkler, Klimaschutzrecht (Lit Verlag, 2005); essay collections such as T. Bonyhady and P. Christoff (eds.), Climate Law in Australia (Federation Press, 2007); G. Van Calster, W. Vandenberghe and L. Reins (eds.), Research Handbook on Climate Change Mitigation Law (Edward Elgar, 2015); M.B. Gerrard and J. Freeman (eds.), Global Climate Change and U.S. Law, $2^{\text {nd }}$ edn (American Bar Association, 2015); E.J. Hollo, K. Kulovesi and M. Mehling (eds.), Climate Change and the Law (Springer, 2013); M. Peeters, M. Stallworthy and J. de Cendra de Larragán, Climate Law in EU Member States: Towards National Legislation for Climate Protection (Edward Elgar g, 2012); academic institutes such as the Center for Climate Change Law at Columbia Law School; and postgraduate programs such as the LLM in Climate Change and Energy Law and Policy at the University of Dundee; the joint LLM in Energy, Environmental and Climate Change Law at the University of Malta and the University of Leuven; the LLM in Global Environment and Climate Change Law at the University of Edinburgh; and the LLM in Climate Change Law and Policy at the University of Strathclyde.

${ }^{74}$ N. Singh Ghaleigh, 'The What, How and Where of Climate Law', in: R. Heffron and G. Little (eds.), Delivering Energy Law and Policy in the EU and US: A Reader (Edinburgh University Press, forthcoming). 75 J.B. Ruhl and J. Salzman, 'Climate Change Meets the Law of the Horse', 62:5 Duke Law Journal (2013), 975, at 985; E. Sherwin, 'Legal Positivism and the Taxonomy of Private Law', in: C.E.F. Rickett and R. Grantham (eds.), Structure and Justification in Private Law: Essays For Peter Birks (Hart, 2008), 103, at 119.

${ }^{76}$ See J.B. Ruhl and J. Salzman, n. 75 above, at 989.

${ }^{77}$ H. Schulze-Fielitz, 'Umweltrecht', in: D. Willoweit (ed.), Rechtswissenschaft und Rechtsliteratur im 20. Jahrhundert (C.H. Beck, 2007), 989, at 990.
} 
objectives, principles, and instruments that engender recognizable patterns and allow a useful distinction from other areas of law. ${ }^{78}$ In perhaps the most rigorous attempt to answer this question, two commentators applied a 'stationarity assessment' borrowed from resource and infrastructure management to conclude that climate change was not sufficiently transformational to warrant 'sweeping doctrinal change' through development of a new field of law. ${ }^{79}$

And yet, it is clear that the advent of climate change has fundamentally impacted law making and implementation across various thematic areas and levels of authority. Several scholars have therefore suggested a more pragmatic definition of climate law as the sum of legal norms pertaining to climate change mitigation and adaptation. ${ }^{80}$ And for the purposes of legal comparison, such a definition might provide a sufficient heuristic, although it also is likely to pose methodological challenges. Unlike established areas of law, many of which have been shaped through systematic application and development over several generations, the legal response to climate change has developed in a far shorter and more arbitrary manner, often triggered by suddenly emerging needs.

As a result, this body of rules neither displays the organized structure, nor the internal consistency and doctrinal strength, of more traditional areas of law. Because of its crosscutting nature, moreover, climate change has prompted the adoption of new rules across a wide range of legal sectors, such as environmental law, energy law, financial services regulation, and planning law, while also affecting core areas of law such as constitutional, administrative, tort, and property law. Its ambiguous boundaries have therefore elicited suggestions that it be considered a transversal area of law with a weak core of proprietary objectives and principles, drawing on more established fields for much

\footnotetext{
${ }^{78}$ W. Erbguth, Rechtssystematische Grundfragen des Umweltrechts (Duncker \& Humblot, 1987), at 24; see also T.S. Aagaard, 'Environmental Law as a Legal Field: An Inquiry in Legal Taxonomy', 95:1 Cornell Law Review (2010), 221, at 242: a 'field of law must exhibit some degree of commonality, a characteristic or set of characteristics shared in common by the situations that arise within the area of law that the field encompasses. Commonalities establish patterns that cohere the field. ... Only when the common characteristics are legally relevant do the materials they encompass appear as an identifiable corpus.'

${ }^{79}$ See J.B. Ruhl and J. Salzman, n. 75 above, at 1013, focusing on climate adaptation. Similarly, calling it a potentially nascent area of law ('in statu nascendi'): S. Schlacke, 'Klimaschutzrecht - ein Rechtsgebiet? Begriffliches, Systematik und Perspektiven', Die Verwaltung, Suppl. 11 (2010), 121, at 152.

${ }^{80} \mathrm{See}$, e.g., with a view to the Australian context J. Peel, 'Climate Change Law: The Emergence of a New Legal Discipline', 32:3 Melbourne University Law Review (2008), 922, at 923: 'an accumulation of case law, legislative development and international regulation that makes up a distinctive body of legal principles and rules identified as "climate change law"; the German context K.F. Gärditz, "Einführung in das Klimaschutzrecht', 49 Juristische Schulung (2008), 324, at 324: 'die Summe derjenigen Rechtsnormen, die das Klima vor anthropogenen Einwirkungen schützen sollen'; for the United States J.C. Dernbach and S. Kakade, 'Climate Change Law: An Introduction', 29:1 Energy Law Journal (2008), 1, at 2: 'The emerging law of climate change is being constructed at the intersection of several areas of law, including environmental law, energy law, business law, and international law.' Because law as a social institution operates through rules that guide human behaviour, the scope of this body of norms would by necessity be limited to our collective and individual responses to climate change, both in terms of addressing its causes as well as protecting against its impacts, see H. van Asselt, M.A. Mehling and C. Kehler Siebert, 'The Changing Architecture of International Climate Change Law', in: G. Van Calster et al., n. 73 above, 1, at 5.
} 
of its normative substance. ${ }^{81}$ In particular, the affinity between legal responses to climate change and the field of environmental law may prove challenging whenever the comparative analysis is levelled at areas of overlap. Because of its historical emergence as an environmental concern, climate change has commonly been framed as a problem of environmental law, with ensuing rulemaking often based on existing legislative and regulatory powers for pollution control, ${ }^{82}$ albeit employing different instruments. ${ }^{83}$ But compelling reasons have been given why this link to environmental law may be counterproductive, narrowing the options available to society in the struggle against a pervasive global threat. ${ }^{84}$

A recent survey of climate legislation in 99 countries worldwide concedes that definitions are 'not clear cut', and chooses to encompass 'legislation, or regulations, policies and decrees with a comparable status, that refer specifically to climate change or that relate to reducing energy demand, promoting low carbon energy supply, tackling deforestation, promoting sustainable land use, sustainable transportation, or adaptation to climate impacts' ${ }^{85}$ As the authors explain, relying on an explicit reference to climate change which might have avoided the foregoing question of ambiguity - would have risked excluding provisions that are relevant to mitigation or adaptation without being deliberately identified as such. While their definition only underscores the lack of normative coherence, it also illustrates that a pragmatic approach to the question at hand can yield very valuable insights. Applying this functional understanding, the survey affirms that the number of climate change laws and policies has doubled every 5 years since 1997, rising from only 54 laws and policies in 1997 to 804 by the end of $2014 .{ }^{86}$ Additionally, it observes that 58 countries have adopted framework laws or policies to address climate change, ${ }^{87}$ attesting

\footnotetext{
${ }^{81}$ See, e.g., H.-J. Koch, 'Klimaschutzrecht: Ziele, Instrumente und Strukturen eines neuen Rechtsgebiets', in: Gesellschaft für Umweltrecht (ed.), Dokumentation zur 34. wissenschaftlichen Fachtagung der Gesellschaft für Umweltrecht e.V. 2010 (Erich Schmidt Verlag, 2011), 41, at 50; proposing its conception as a 'procedural overlay' with coordinating functions across different areas of law, see J.B. Ruhl and J. Salzman, n. 75 above, at 1019 .

${ }^{82}$ Tracing how climate change has been situated within environmental law as a 'typical pollution problem': J.C. Nagle, 'Climate Exceptionalism', 40:1 Environmental Law (2010), 53, at 88.

${ }^{83}$ Contrasting the use of ambient environmental quality targets in most areas of conventional pollution control to the mass- or rate-based emission limitation and reduction targets prevalent in legislation and regulation on the mitigation of climate change: C. Hilson, 'It's All About Climate Change, Stupid! Exploring the Relationship Between Environmental Law and Climate Law', 25:3 Journal of Environmental Law (2013), 359 , at 364-365.

${ }^{84}$ C.P. Carlarne, 'Delinking International Environmental Law and Climate Change', 4:1 Michigan Journal of Environmental \& Administrative Law (2014), 1, at 4. While Carlarne levels her challenge against the consignment of climate change within the boundaries of international environmental law, many of her arguments for mainstreaming climate change across legal fields also hold ground on the domestic plane.

${ }^{85}$ See M. Nachmany et al., n. 50 above, at 30.

${ }^{86}$ Ibid., at 12; approximately half of these acts were passed by the legislative branch, and the other half by the executive branch.

${ }^{87}$ Describing these as laws, or regulations with equivalent status, that serve as a comprehensive, unifying basis for climate change policy and address multiple aspects or areas of climate change mitigation or adaptation (or both) in a holistic, overarching manner. Ibid., at 28.
} 
their particular importance in driving climate action. ${ }^{88}$ And finally, while 45 countries accounting for over 75 per cent of global emissions have adopted economy wide mitigation targets for 2020 or beyond, it finds that a majority of countries have at best minimal climate change risk assessments. ${ }^{89}$

Clearly, the degree of normative development in areas relevant to climate change mitigation and adaptation has been nothing short of remarkable. Yet despite this unprecedented proliferation, it would seem prudent to assume that climate change has not yet given birth to an autonomous field of law. Still, as the foregoing survey shows, even an intuitive definition of the legal responses to climate change can serve as the basis for useful analysis. For the time being, therefore, a pragmatic approach to the issue of tertium comparationis will arguably be the best we can hope for, compelling the comparative lawyer to be transparent about conceptual assumptions and terminological limitations. But even if a nascent body of common objectives and principles may eventually justify conceding the existence of a distinct field of 'climate law' - perhaps, as some have suggested, in the sense of a 'procedural overlay' that cuts across various affected areas of law $^{90}$ - comparative lawyers will play an important role in populating its substantive doctrines and facilitating its understanding. For, as an eminent jurist once observed, the 'history of a system of law is largely a history of borrowings of legal materials from other legal systems ${ }^{91}$ - and what approach could be more ideally suited for studying this process than comparative analysis?

\section{QUESTIONS FOR COMPARATIVE ANALYSIS}

If lawyers commit to the study of climate change and its manifestations in our legal system, what, then, are suitable questions for comparative analysis that harness the distinct potential of an internal perspective on the law? At first glance, such a narrowed focus of enquiry would seem to place severe limitations on the types of issues amenable to comparative legal analysis, yet an exploratory survey suggests abundant opportunities for lawyers to make authoritative and relevant observations based on their training and professional sensibilities. Such issues include:

- the role of the legal tradition, such as civil or common law, and underlying legal culture in how climate change is framed in the legal system;

- the influence of constitutional organization, including federal or unitary structure, or allocation and separation of legislative, executive and judiciary powers, on climate policy development and implementation;

- vertical and horizontal interactions between and within legal systems, and coordination thereof;

\footnotetext{
${ }^{88}$ Ibid., with reference to S. Fankhauser, C. Gennaioli, and M. Collins, Domestic Dynamics and International Influence: What Explains the Passage of Climate Change Legislation? (Grantham Research Institute on Climate Change and the Environment and Centre for Climate Change Economics and Policy, 2014).

${ }^{89}$ See M. Nachmany et al., n. 50 above, at 12.

90 See J.B. Ruhl and J. Salzman, n. 75 above, at 1019.

${ }^{91}$ R. Pound, The Formative Era of American Law (Little, Brown, 1938), at 94.
} 
- sectoral assignment of climate change within the legal system - for instance to environmental or energy law - and the corresponding institutional portfolio in the legislature and administration;

- the normative hierarchy of relevant law, from constitutional provisions to statutory and substatutory law, such as regulations and decrees, and the impact thereof on the weight of climate change within the legal system;

- the legal nature of objectives and principles on climate change, how these are operationalized, and whether they can serve as grounds for judicial action;

- the systematic structure of relevant law, from central statute on climate change to a portfolio of individual laws and regulations;

- legislative and rulemaking processes, and the effects of differences in voting requirements, lawmaking procedures, and stakeholder participation;

- the impact of individual rights and freedoms on the scope of climate constraints, and the principles used to balance tensions or conflicts; and

- the role and prospects of climate litigation, for instance regarding rules of evidence, concepts of causation, legal standing, and legal responsibility.

Needless to say, this is only a partial list, yet already it is evident that there is no shortage of questions whose answer requires an understanding of the legal system and the methods and substantive doctrines of the law, thereby drawing on the specific skills of lawyers. Potential insights from such enquiry are by no means limited to abstract legal doctrine, and can have numerous ramifications for climate action in practice.

Under the heading of vertical and horizontal interactions between and within legal systems, for instance, researchers can ask whether certain particularities of domestic law promote or impede international cooperation, ${ }^{92}$ or how international commitments may influence lawmaking at the domestic level. ${ }^{93}$ Likewise, they can trace how legal concepts and principles have been transplanted across jurisdictional boundaries, and whether such transplants have aligned successfully with their new legal environment and the legal doctrines and principles observed therein. ${ }^{94}$ Both types of interactions have arguably gained in importance lately, as climate cooperation between States has shifted from traditional diplomacy to new forms of engagement captured in notions such as

\footnotetext{
92 Legal constraints can limit the ability of a nation State to negotiate and ratify international treaties, or denying subnational jurisdictions the ability to engage in diplomatic relations, see, for instance, D.A. Wirth, 'The International and Domestic Law of Climate Change: A Binding International Agreement Without the Senate or Congress?', 39:2 Harvard Environmental Law Review (2015), 515, at 532.

93 Applying an econometric methodology: S. Fankhauser, C. Gennaioli and M. Collins, 'Do International Factors Influence the Passage of Climate Change Legislation?', Climate Policy (forthcoming, 2015)

94 O. Kahn-Freund, 'On Uses and Misuses of Comparative Law', 37:1 Modern Law Review (1974), 1, at 5; A. Watson, 'Legal Transplants and Law Reform', 92 Law Quarterly Review (1976), 79; for an application to the environmental context, see J.B. Wiener, 'Something Borrowed for Something Blue: Legal Transplants and the Evolution of Global Environmental Law', 27:4 Ecology Law Quarterly (2001), 1295.
} 
'multilevel', 95 'polycentric', ${ }^{96}$ or 'transnational' law, ${ }^{97}$ yet they also highlight how quickly the boundaries between fact and norm begin to blur. As societies evolve and changing circumstances strain the persuasiveness of jurisprudential orthodoxy, new labels such as the foregoing will periodically gain currency, ${ }^{98}$ offering explanatory value by refracting our understanding of legal responses to novel trends or developments. But lawyers opting to apply an internal perspective of the law need to remain vigilant when hoping to infer normative consequences from such novel paradigms - for the time being, these only offer an alternative perspective on the law, without themselves inducing any changes to the underlying legal doctrines and normative relationships. ${ }^{99}$

Where comparative analysis reveals differences in the way two or more legal systems address a challenge, lawyers can help discern which underlying factors have their origins in law, as opposed to the broader socio-economic context. Yet even where divergence can be traced back to legal particularities, no normative consequences will necessarily follow: the difference can simply be a given, and its observation may merely add to our understanding of the way law shapes behaviour. In rare cases, however, the explanation may itself possess normative force, for instance when a common feature across jurisdictions is indicative of a general principle of law, or provides evidence of habitual practice that indicates custom. Some authors even hope to derive universal precepts from

95 J. Peel, L. Godden, and R.J. Keenan, 'Climate Change Law in an Era of Multi-Level Governance', 1:2 Transnational Environmental Law (2012), 245; B.G. Rabe, 'Beyond Kyoto: Climate Change Policy in Multilevel Governance Systems', 20:3 Governance (2007), 423; J. Scott, 'The Multi-Level Governance of Climate Change', 5:1 Carbon \& Climate Law Review (2011), 25.

${ }^{96}$ E. Ostrom, A Polycentric Approach for Coping with Climate Change: Background Paper to the 2010 World Development Report (World Bank, 2010); H.M. Osofsky, 'The Geography of Solving Global Environmental Problems: Reflections on Polycentric Efforts to Address Climate Change', 58 New York Law School Law Review (2013-2014), 777; B. Sovacool, 'An International Comparison of Four Polycentric Approaches to Climate and Energy Governance', 39 Energy Policy (2011), 3832.

97 L.B. Andonova, M.M. Betsill, and H. Bulkeley, 'Transnational Climate Governance', 9:2 Global Environmental Politics (2009), 52; H. Bulkeley et al., Transnational Climate Change Governance (Cambridge University Press, 2014); H. Bulkeley, 'Transnational Environmental Governance: New Findings and Emerging Research Agendas', 30:4 Environment and Planning C: Government and Policy (2012), 556; T. Etty et al., 'Transnational Dimensions of Climate Governance', 1:2 Transnational Environmental Law (2012), 235.

98 Recall, for instance, the impact on the contemporary legal debates at different points in time of structuralism and post-structuralism in literary science and linguistics, the positivism debate in the social sciences, or systems theory in biology and cybernetics, each of which introduced new concepts and left temporary, and in some cases permanent marks, on jurisprudence.

${ }^{99}$ In other words, legality or the absence thereof will remain unaffected, whether an alternative perspective such as 'transnational law' is applied or not; what such a paradigm offers is - no more and no less - the ability to highlight trends or correlations which an orthodox perspective fails to capture. When 'transnational' law, for instance, seeks to broaden the scope of enquiry to include private standards and codes, for instance, it cannot afford these instruments a legal status they otherwise lack. Over time, however, it is conceivable that, by refocusing attention on previously underappreciated facets of the law and its application, such paradigms can impel judicial bodies to change their interpretation of the law, or even prompt legislators to elaborate new law, resulting in very real normative consequences. 
comparative study in order to support elements of a general theory of law, ${ }^{100}$ yet there, too, caution is warranted against reaching overly eager conclusions.

\section{OUTLOOK}

Climate change defies traditional models of academic enquiry; its scale and complexity strain the explanatory power of established thought. Frustration over these limitations and the urgency of the underlying threat have motivated the pragmatic espousal of fluid concepts, with forceful calls for greater interdisciplinarity also resulting in a certain degree of methodological opportunism. Law, characterized by rigid doctrines and an ostensibly dated insistence on reducing the pluralism of reality to a matrix of binary norms, may appear particularly inadequate as a framework of analysis. Unable to draw on the persuasive force of empirical analysis and quantified prescription, it has, unsurprisingly, had far less of an impact on the broader climate debate than the natural and social sciences.

But as this article has argued, the legal method offers a unique vessel to infer collective understandings on the causes and effects of climate change and its implications, as mediated by the totality of social aspirations and concerns embedded in the law. In doing so, it helps bridge the divide between facts and norms, affording it a vantage point that is unique among purely empirical or normative disciplines. Unlike economics, moreover, it does so not on the premise of an abstract theoretical paradigm, but based on the expression of consensus formally vested in the law. As the focal point of climate action shifts from international diplomacy to domestic policies and measures, lawyers can harness comparative analysis to enrich our understanding of the development and implementation of domestic climate action across jurisdictions.

Going forward, as the body of rules with a bearing on climate change continues to expand and eventually may give rise to a new area of law, comparative lawyers might be charged with assessing whether and to what extent national legislation is sufficiently aligned to meet the intended nationally determined contributions of different jurisdictions, or how domestic policy efforts, studied within their normative context, might compare to each other. Beyond highlighting aspects that other disciplines might overlook, such as barriers to policy development originating in the normative sediment of society, comparative legal analysis can access the collective will embedded in the law to help interpret technically complex and morally contingent parameters of action, or help balance conflicts between multiple social ends.

In the end, therefore, the comparative project extends beyond instrumental study into the epistemology of climate action. Where law embodies the very circumstances that have precipitated our climate crisis, however, detached enquiry may not always be enough. Like other academics, lawyers are challenged to perpetually question how their discipline helps uphold the forces that contribute to climate change, and, without severing the fragile

\footnotetext{
${ }^{100}$ P. Lepaulle, 'The Function of Comparative Law with a Critique of Sociological Jurisprudence', 35:7 Harvard Law Review (1922), 838, at 855-857.
} 
filament of normative legitimacy that ties the law to its consenting subjects, reweave its fabric through defensible interpretation for a more sustainable, just and inclusive world.

Michael Mehling is Executive Director of the Center for Energy and Environmental Policy Research at the Massachusetts Institute of Technology (MIT) and a Visiting Professor at the University of Strathclyde. He also is the founding editor of the Carbon \& Climate Law Review, the first academic journal focused on legal aspects of climate change. He gratefully acknowledges comments by Harro van Asselt, David Driesen, Elisa Morgera, Eleanor Stein, and an anonymous reviewer. Any errors are, of course, his responsibility alone. 